\title{
Exemplary Teachers' Understandings of Writing Instruction for Students with Disabilities Included in Secondary Language Arts Classes: It's a Beautiful Struggle
}

\author{
Mary Theresa Kiely \\ Queens College, The City University of New York
}

\begin{abstract}
Teaching writing well poses several challenges in today's diverse classrooms. Despite a growing research base on teaching writing, outcomes for students with disabilities in secondary schools continue to be disappointing. Research in the naturalistic tradition that would help educators understand the knowledge and beliefs that influence teachers' practice, however, is scarce. Specifically, researchers know little about how exemplary general education teachers, who often have little to no training in special education, think about writing instruction for students with disabilities. To investigate teachers' understandings and practices for supporting students with disabilities, interviews, observations, and artifacts were analyzed using qualitative methods. Exemplary teachers' understandings of writing instruction for students with disabilities who are included in 9th-and 10th-grade general education language arts classes included deep and integrated knowledge of content and pedagogy that enabled them to facilitate the students' progress. Teachers had firm beliefs that (a) students with disabilities could make progress and (b) learning writing was vitally important. Teachers' understandings of writing instruction for students with disabilities were influenced by their knowledge of content and pedagogy, their beliefs about students and writing, and the contexts within which they worked. Implications include a call for more research about (a) the relationship between teachers' beliefs and their practices, (b) opportunities to engage in context-embedded professional development, and (c) the amount of time necessary to reflect
\end{abstract}


on, respond to, and deliver meaningful feedback in a sustained dialogue about writing for students with disabilities.

Learning to write is challenging and demands coordination of complex processes. In the simplest processes, the writer is applying words to the page and the writing event ends there. In knowledge transforming (Bereiter \& Scardamalia, 1987), the writer is also planning, organizing, and revising with attention to the writer's goals. Students may encounter difficulties in several of these writing processes; however, researchers are still working to understand how teachers can help all students succeed in writing (Adams \& Engelmann, 1996; Graham et al., 2016). In the United States, only 27\% of eighth graders scored at or above the proficient level in the national writing assessment; even fewer diverse learners were scored proficient: $11 \%$ of Black students, $14 \%$ of Hispanic students, and 16\% of English language learners and students with disabilities (Snyder, de Brey, \& Dillow, 2018). Because of the complexity of teaching writing well for students in our diverse, inclusive classrooms, it is crucial that educators understand the importance of knowledgeable, skilled teachers.

Some research-supported ways teachers can help all students succeed in writing include: repeated practice, the use of self-regulation strategies, progress monitoring, enhancing motivation, and supporting collaboration (Kiely, 2017). Technology can be used as a teaching tool as well as a motivational aid. Research has supported teaching explicit instruction strategies for secondary students, using a model-practise-reflect instructional cycle (Graham et al., 2016). Also recommended were integrated reading and writing instruction and the use of assessment to guide instruction. For teaching students with disabilities, the most effective approaches include: explicit, direct instruction in specific strategies and skills (Adams \& Engelmann, 1996); using the writing process model (Troia \& Graham, 2002); teaching strategies for self-regulation (Graham, Harris \& Mason, 2005); and supporting self-determination and motivation (Wehmeyer, Shogren, Toste, \& Mahal, 2016). General education language arts teachers deliver most of the instruction for included students with disabilities (Snyder et al., 2018), and the knowledge and skills of their teachers play a large part of the success these students experience. But it is now starting to be clear that to meet students' needs, teachers will have to be knowledgeable in more areas than before as well as skilled in effective collaboration.

Many different types and conceptions of teacher knowledge and knowledge for teaching appear in the literature (Fenstermacher, 1994; Fernandez, 2014; Munby, Russell, \& Martin, 2001; Shulman, 1986). Researchers have shown the influence of teacher knowledge, beliefs, and practices on student achievement, and their importance to teacher effectiveness in general; but it is becoming clearer that the role of pedagogical content knowledge, specific to the subject area and students within a particular context, is important to student achievement outcome measures (Graham, Harris, MacArthur, \& Fink, 2002; Grossman \& Stodolsky, 1995; Hiebert, Gallimore, \& Stiegler, 2002). Pedagogical content knowledge includes not only the subject matter knowledge, but also knowledge of how to teach the subject in a way that is meaningful to students (Grossman, Wilson, \& Shulman, 1989). 
The specific context in which teaching and learning takes place also influences and shapes teachers' understandings of what and how to teach (Grossman \& Stodolsky, 1994; Talbert, McLaughlin, \& Rowan, 1993). Contextual influences include student demographics, class characteristics, school characteristics such as administrative strength and teacher collegiality, district support for teacher learning, state testing requirements, and federal legislation, for example. Teachers' work is situated within a number of contextual levels, each of which influences that work in some way.

Finally, a substantial number of studies have shown the powerful influence of teachers' beliefs in shaping what they know and do, and even what they are able to learn (Kiely, Brownell, Benedict, \& Lauterbach, 2014; Fang, 1996; Jordan, Glenn, \& McGhieRichmond, 2010). Linking beliefs to practices is important because beliefs underpin teachers' decision making and so are an essential consideration for efforts to improve teacher practice (Buehl \& Beck, 2014). Among the kinds of beliefs researchers have linked to teachers' practices relative to students with disabilities included in general education classrooms are: teachers' beliefs about themselves as teachers (e.g., Bender, Vail, \& Scott, 1995), beliefs about the subject area or discipline (Kang \& Wallace, 2004), beliefs about teaching and learning (Cunningham, Zibulsky, Stanovich, \& Stanovich, 2009), beliefs about students with disabilities (Jordan et al., 2010), and beliefs about inclusion (Moni et al., 2007).

Research about teachers' beliefs and students with disabilities, however, is limited (Kiely et al., 2014). It includes research on teachers' beliefs about: inclusion (e.g., Scruggs \& Mastropieri, 1996), instruction and assessment (e.g., Berry, 2006), students with disabilities (e.g., Jordan et al., 2010) and teachers' self-efficacy beliefs (Coladarci \& Breton, 1997). Learning more about the potential of students with disabilities placed in their classrooms is vitally important to students; teachers' beliefs shape the teacher's entire approach to an individual student's learning (Pajares, 1992).

Understanding effective instruction is an important step in understanding the resources and knowledge required to ensure students' success. The purpose of this study, therefore, was to investigate how exemplary teachers understand writing instruction for students with learning disabilities included in 9th and 10th grade general education language arts classes. Specifically, research questions included:

1. How do exemplary general education teachers, who often have little to no training in special education, think about writing instruction for students with disabilities?

2. How do exemplary general education teachers support writing for students with disabilities included in the general education classes?

3. How do exemplary teachers' understandings of the needs of students with disabilities shape their decisions about content and pedagogical approaches in writing? 


\section{Methodology}

The study was designed as exploratory and descriptive and relied on interviews with teachers, observations of teachers, and review of artifacts. At the time of the study, I was a faculty member in special education with 10 years of experience in teaching writing to students with disabilities at the high school level.

\section{Participants}

Participants were purposively sampled from high schools in a small city in Florida, U.S.A. I talked with English department chairs, special education teachers, and language arts teachers in four schools to find teachers who might be interested in talking with me about teaching students with disabilities and students who struggle with writing in the general education classroom. Then, I asked the principals whether they knew any language arts teachers who seemed to have a high level of knowledge and expertise in addressing the needs of students with disabilities. After listening to one principal speak of his strong interest in inclusion and another of his commitment to writing instruction, I selected three teachers in those two schools. I found no suitable participants in the other two schools. Each of the three selected participants had five or more years of experience, taught 9th- or 10th-grade language arts classes that included students with disabilities, and was recommended by their peers or administration as someone who seemed to know a lot about teaching writing to students who find writing to be a challenge. The students with disabilities included in the participants' classes: (a) were provided access to the general education curriculum, (b) participated in all testing, and (c) were working toward a diploma. Seven class periods each lasted 50 minutes.

All participants were female, consistent with national data showing about threequarters of teachers are female (Snyder et al., 2018). Elizabeth worked in a high school that enrolled 2,055 students; $36 \%$ of students were eligible for free or reduced-price lunch (Florida Department of Education, 2008) and $18.3 \%$ were identified as students with disabilities. Her classes each had approximately 30 students, of whom 6 to 8 were students with disabilities, or $20 \%$ to $27 \%$. An additional 2 or 3 students per class were identified as ESOL, or having a first language other than English. She had 5 years of experience; her undergraduate major was journalism, and she had a master's degree in English Education. Nancy and Lillian worked at a school that had 1,956 students; $43 \%$ of students were eligible for free or reduced-price lunch and $22.3 \%$ were identified as students with disabilities (Florida Department of Education, 2008). Six hundred students in the school participated in an International Baccalaureate program housed at the school. Both teachers had more than 20 years of experience. Their regular classes consisted of no more than 22 students; there were more students in honours and advanced placement classes. Students with disabilities comprised $25 \%$ to $50 \%$ of students in their regular classes. Both teachers had a bachelor's degree in English Education.

\section{Data Collection and Analysis}

Spradley's (1979) method is inductive: the themes emerged from the data analysis using the constant comparative method of analysis. The method is a way of creating 
theory, and the descriptions of the relationships among the categories is considered theory. The data were then considered in light of relevant theory from the literature.

Each participant was interviewed either three times or four times and observed at least twice. Interviews lasted an hour or more. Interview questions were designed to elicit thoughtful, elaborated responses; and probes were used to clarify specific areas of concern and confirm researcher conclusions in later interviews. For example, teachers were asked how they would define writing, how writing instruction was different for students with disabilities, and how they organized writing instruction across the school year. Participants also clarified responses to previous interview questions through email upon request. After the initial interview, teachers were observed during writing instruction. Subsequent interviews took place after each observation. Field notes were taken by hand during observations and were used to compose questions for subsequent interviews. Interviews were coded throughout the data collection in a recursive process moving from coding, generating questions about the data, recoding, and clarifying to each data collection event. Teachers also provided lesson plans, handouts, materials, and samples of student work related to the observed lessons for analysis. These artifacts were also used to generate further interview questions about the work teachers were doing with students with disabilities.

Interviews were recorded and transcribed, then coded according to the 12-step method proposed by Spradley (1979). Codes were generated from the data, then sorted and placed into domains or categories. The codes were then analyzed; some were eliminated, refined, combined with others, or made into separate codes. Others were split into two or more dimensions. See Table 1 for sample codes and categories.

Domains emerged from the analyzed codes. For example, one code was "steps in the writing process." This became incorporated with the code "the six traits of writing" under the dimension "ways to organize writing instruction," which later was placed in the domain "Content Area Knowledge." Componential analysis of the domains, both within each domain and across all of the domains, was accomplished through the use of the constant comparative method. The constant comparative method of inductive analysis was used to refine categories of data, and I purposefully looked for negative evidence, that is, evidence that cannot be explained within the emerging analysis, throughout the process. Specifically, I first identified the relevant bits of data and gradually was able to discern relationships among the bits of data. By thinking about and comparing each bit of data to other bits of data, I identified relationships between them. Then I refined categories of data. The constant comparative method is sequential and recursive analysis; each new bit of data is compared to the coded data and to the emerging categories. Relationships among the data, the categories, and the domains were sought and rethought in light of the whole emerging analysis again and again until the categories contained consistent data in a logical relationship to the other categories. Categories were organized into a taxonomy, and through taxonomic analysis, the structure of the domains themselves and their relationships to one another were considered. Data were sought until the categories were saturated. 
Table 1.

Sample Codes, Dimensions and Domains of Exemplary Teachers' Understandings of Writing Instruction for Students with Disabilities Included in Secondary Language Arts Classes

\begin{tabular}{|c|c|c|}
\hline Domains & Dimensions or Categories & Example Codes \\
\hline \multirow[t]{5}{*}{ Content } & Sources of knowledge & Own writing teachers \\
\hline & Definitions of writing & Communication \\
\hline & Parts of teaching writing/ways to organize instruction & Steps in the writing process \\
\hline & Outcomes of writing instruction & Display their thoughts accurately \\
\hline & Rationale for instructional/curricular choices & Challenges faced by students with disabilities \\
\hline \multirow[t]{5}{*}{ Pedagogy } & Motivation & Finding out what really does matter to them \\
\hline & Scaffolding; multiple opportunities for success & Support for struggling writers \\
\hline & Need for individualized instruction & How writing instruction differs for students with disabilities \\
\hline & Importance of connections with students; affective needs & Ways to respond to struggling learners \\
\hline & Repetition & Kind of a creative re-presentation \\
\hline \multirow[t]{2}{*}{ Beliefs/Values } & Importance of writing & Success in the future \\
\hline & Expectations for students & Move forward \\
\hline \multirow[t]{4}{*}{ Context } & School characteristics & Class size \\
\hline & District influence & Placement issue \\
\hline & State testing; state policy & Impact of policy \\
\hline & Federal policy & Inclusion, mainstreaming, philosophy of \\
\hline
\end{tabular}




\section{Trustworthiness}

Throughout the analysis process, the constant comparative method and the search for negative evidence helped to ensure the integrity of the interpretations. In later interviews participants were also asked specific questions related to my interpretations, a form of member checking. Multiple sources of data - interviews, observations, and artifactsalso bolster the trustworthiness of the conclusions. Two of the 10 interviews were each coded independently by two doctoral student researchers. Before coding, the emerging codes were presented and discussed with examples within two meetings lasting 90 minutes each. After coding, we discussed the coding and clarified the codes in a final 90minute meeting.

\section{Results}

Four major domains in exemplary teachers' understandings of writing instruction for students with disabilities included in the general education classroom emerged from the data: teachers' knowledge of the content, teachers' knowledge of pedagogy, teachers' own beliefs and values, and the contexts within which instruction occurred. Teachers' understandings of writing instruction for students with disabilities were shaped and supported by the various dimensions of these domains, shown in Table 1. Complex relationships existed both among the dimensions of each domain and among the domains themselves that contributed to teachers' understandings of instruction for their students with disabilities.

\section{Teachers' Knowledge of Content}

The teachers had a deep and thorough knowledge of the subject area, writing. They spoke explicitly about the larger goals of writing instruction and about how they selected and sequenced content to meet the needs of their students. Although they claimed they treated their students with disabilities the same as any other student, with the exception of providing accommodations specified in the individual education plans, their deep knowledge of writing and the needs of their students combined to enable them to devise approaches to the content that were consistent with recommendations in the special education literature. For example, they were able to select the most essential parts of the curriculum and focus heavily on them, and they were able to break large tasks down into manageable parts. This section focuses on how teachers' knowledge of the content area enabled them to support students with disabilities.

Teachers' definitions of writing were broad and situated the act of writing within the larger framework of communicative processes. "I would define writing as expressing your thoughts in a clear and useful way. On paper," said Elizabeth. The emphasis is on the expression of ideas, not the mechanical act of writing. "I would say it is expressing what's in your head, by yourself on paper, most of the time" (Lillian). Lillian echoed Elizabeth and Nancy's emphasis on expression. "It's one of the major ways people communicate," said Nancy, explicitly situating writing within the realm of communication rather than conceiving of it as a discrete activity to be learned and practised in isolation. 
These broader definitions of writing enabled these teachers to consciously reinforce their writing instruction through other communicative processes and various modes of writing. "So that, that's a writing assignment, but the final product of that is a visual, even though it is a writing assignment" (Nancy). This teacher strengthened students' capacities to execute the thought processes that go into a traditional piece of writing with assignments that allowed students to practise those processes in ways other than writing essays. Lillian said, "I also get them started writing journals to try to build fluency and to get them used to expressing themselves on a regular basis." This revealed her awareness of student needs and her use of content knowledge to help students build the skills they would need to complete more demanding and more formal writing tasks successfully.

Their knowledge of the content base supported their ability to organize instruction in a manner that addressed the needs of students with disabilities. The teachers believed that students with disabilities could make progress in the content. "I try to assign the same stuff and expect the same, expect them to go through the same process and the same readings and the same, um, you know, the same kinds of things as the other kids," (Lillian). The teachers' rationales for instructional and curricular choices provide evidence that their instruction was, in effect, designed with the needs of struggling learners built in:

We have such a range of students, and therefore, we have such a range of issues. And, and also beautiful things and joys in their writing. So I guess we just sort of, it's kind of second nature. We just try to meet them where they are. Or, at least, I do. (Lillian)

Lillian was aware that her students had a variety of needs: "We have such a range of issues," and that her instruction had to be driven by those needs: "We just try to meet them where they are." The teachers use their content knowledge to select tasks and activities to meet those needs. They also conceived of writing instruction, in general, as rather more individually focused in nature than instruction in other areas.

Well, you try to do shorter tasks, like OK, this can be accomplished in the time we have in class, and then tomorrow we'll finish it. And for me, I have a writing folder that they put their writing in and I keep it. And then, give it back out again, so that they have it. I think that for that kind of student, they seem to like the highlighting of their work, to be able to see vividly and physically interact with it. (Nancy)

Nancy's comments show she was able to use her knowledge of content to create tasks to meet her instructional goals that also took into consideration her students' needs for support and guidance: "This can be accomplished in the time we have in class." She is aware of their need for instruction to be concrete and explicit, and has students highlight structural elements of their writing to provide a visually exciting and hands-on way for students to analyze their writing. She also addressed her students' propensity to struggle with organization of the multiple tasks that are required of high school students by keeping their work in folders for them, in the classroom.

Teachers were also able to use their knowledge of content to design instructional activities that provided students with support and opportunities for practice:

I want us to constantly practise things. And the reason for the different columns, not just like doing it again, my goal is, with most everything, we do one time, we do something together as a class. The second time, they have some freedom, but then we go over it as a 
class, so that they kind of tie back. Sometimes we do that level as a partnership.... And then the last time, they're on their own. They've done it as a group, they've done it on their own with the check as a group, and then they do it all on their own. So, it just kind of like steps them into being able to take the authority themselves. (Elizabeth)

The teacher in this instance chose to focus on elaboration, a vital component of writing well and one with which most students who struggle to write well have great difficulty. The lesson entailed student generation of sensory detail about a given subject with gradually increasing levels of independence, serving to bolster students' understandings of the task, support students' attempts at the task, and provide supervised opportunities to practise the task. The activity subsequently enabled students to focus on other aspects of writing during later lessons, as they were able to draw from the ideas and images they had generated in this lesson:

And then, once they have a set of details, they can write from that, from those details, better than just details they could come up with. And then when they write like seven really good sentences, they feel good about it, and they actually are willing to try the eighth and the ninth sentence, as opposed to, like, I'm out of ideas. I'm just going to sit here and stare at the wall. (Elizabeth)

Elizabeth broke the task down into smaller tasks, but because her knowledge of the content she was teaching was integrated and thorough, the smaller tasks she chose addressed several of her students' needs and linked meaningfully to both a later, specific lesson and her larger curricular goals for her students. She was also sensitive to students' affective need to feel successful in academic tasks and believed her students' successes were motivating for them.

These teachers all had 5 or more years of experience; two had more than 20. It is not surprising, then, perhaps, that they attributed their knowledge of how to teach writing mostly to experience. "Mostly I would say it's from personal experience," said one teacher (Elizabeth). Nancy similarly agreed:

A lot of it is experience [laughs]. But you know, we do workshops and things like that, but, and I've had, interestingly enough, a lot of young, contact with young people through them being interns? And, the theory is I'm supposed to help them, but in reality, it's been truly a mutually learning situation.

Nancy valued her contact with interns and the knowledge of new research they brought to her classroom. The teachers also spoke of the importance of workshops, inservice training, and keeping up with the professional literature as important components of their knowledge. None attributed their knowledge of writing to the teacher training they had completed in college.

\section{Teachers' Knowledge of Pedagogy}

Teachers' knowledge of pedagogy in general supported their understandings of instruction for their students with disabilities. Their rationales for activities, lessons, and curricular emphases reflected their knowledge of student needs in the areas of motivation, individualized instruction, making personal connections with students, the influence of students' affective states, and repetition. 
Teachers drew on their knowledge of content, knowledge of student needs, knowledge of pedagogy, and knowledge of context to motivate their students. Teachers motivated students by making content meaningful to them. "If you teach writing all on its own, students are never going to see the meaning, the purpose of it. Unless it's integrated into other things that matter to them" (Elizabeth). Teachers accomplished meaning making by linking writing to literature, providing students with meaningful writing opportunities, using multimedia to capture students' interest, and ensuring all students had the opportunity to be successful in some way:

If you teach the setting and writing about proper characters and character development at the beginning, in the ideas category, they're more likely to have a better foundation for where they're headed. Then they actually have something interesting to write about, so they can eventually care about their conventions in that writing. (Elizabeth)

Elizabeth linked her writing instruction with her literature instruction in an intimate way so that instruction in the one directly informed the other, while also building students' background knowledge in both. She provided students with the opportunity to write about "something interesting" so that they would be motivated to learn more about other aspects of writing.

Lillian had students write to an audience of eighth graders about what was ahead for them in the ninth grade. Her rationale for the choice of subject matter was entirely motivation:

So they have real audiences. And I got more work turned in than I typically do. And, so I think that just knowing that they could maybe have an impact on another person, and then that they kind of are the authority, because they've had the experience that the 8th grader is going to have. I think it was empowering. (Lillian)

Lillian understood that academic tasks are often disconnected from students' lives, and she drew on her knowledge of content and pedagogy to create an assignment that would appeal to students by casting them as "the authority," also reinforcing her aim to show students she believed that they possessed useful knowledge. She provided her students with a real reason for writing: to give advice to a younger student and share their experience.

Teachers also motivated students by using various media, but to more varying degrees than was evident in the other dimensions. One teacher reported no use of multimedia at all. Another confined her use of multimedia to non-technological media, such as pictures, drawings, post-it notes, and highlighters. Elizabeth made frequent use of media, particularly film clips, to motivate students. For example, in the lesson on generating sensory details referred to previously, she first had students observe approximately 3 minutes of the opening scene of a movie in order to help students understand the meaning of sensory detail:

I just want them to practise the thought process of looking at all five senses, thinking, what would it smell like if I was there? What would be the sounds, not just the sounds of the movies, but what kinds of things would you hear? And it's more of a visualization, because, until they visualize it, they won't be able to write it. I really want them, when they read and when they write, to mentally get into it, to be in that place and time, and then they can be more descriptive when they write. And some of them have a really hard time with that. I 
mean, looking at their reading skills, so many of them, when they read something, they don't create a mental movie of it. And I really want them to create that mental view of what it was and what it looked like. On their own. And obviously they pull from what they're reading, but then I want their imaginations to pick up. So, they kind of have to exercise their imaginations. (Elizabeth)

Elizabeth motivated her students by creating an experience for them that allowed them to practise the actual thought process necessary to generate sensory details, but scaffolded it by providing them with the experience through technology. The film clip made the activity more accessible to students because it motivated them and relieved them of the necessity to conduct two thought processes at one time: visualizing a scene and analyzing that scene in terms of sensory detail. Her knowledge of the content area also allowed her to make links to other areas of the curriculum, specifically, literature and reading. Her knowledge of her students, content area, and pedagogy supported her design of an activity that benefitted students in several ways. Her goals are quite clear: She wants students, when they read, "to mentally get into it," and "exercise their imaginations," and when they write, "to be more descriptive." Familiarizing students with expected tasks increases their confidence that they can successfully complete such tasks, an important component of motivation.

Teachers also built students' confidence and familiarity with tasks by breaking tasks down into their component parts and gradually withdrawing support. Teachers thus facilitated students' ability to achieve some degree of success. This technique is also known as scaffolding (Bruner, 1978), and teachers' abilities to scaffold student learning effectively draws on their knowledge of content, pedagogy, and students:

I wanted them to see that OK, maybe I had one idea, or eight ideas, or whatever, but to see that there were a lot of different ideas, and to see that, oh, we can group them, we can categorize them. And I find with the [student with disabilities] in particular, but really with all the regular students, that they really benefit from an incremental approach with scaffolding. But my goal is to try to get as many kids to participate and to sort of increase their interest and to get all sorts of ideas up there. And then to practise together that grouping. (Lillian)

Lillian explicitly linked scaffolding with motivation in her rationale: "scaffolding" served her goal to "increase their interest." She supported students' writing in this activity by helping them not only to generate, but also to organize ideas for writing, and reinforced their learning through "practice together" in hopes of "get[ting] as many kids to participate" as possible. Rather than just give students an assignment to brainstorm and make an outline for an essay, she walks them through the generation and organization of ideas in class, thus motivating them to complete the larger writing assignment. Elizabeth echoed her ideas:

Attainable pieces, where they can feel success. Throwing the whole thing at a lot of them, especially my kids with special needs, they're just going to turn off. "Oh, I can't do this now." Everybody can write a paragraph.... So, I just like to break it down into attainable pieces. And then, we put it together, and they see "Wow, I can write!" And that's a lot of what this assignment is. "I can write." And once they know they can write, they're willing to try. (Elizabeth) 
The "attainable pieces" made students "willing to try." Elizabeth was also able to use her knowledge of content, pedagogy, and students to craft instructional activities that not only helped students build knowledge and skills, but also enhanced students' motivation to perform and were integral to her curriculum in writing as a whole.

Teachers' knowledge of pedagogy and students also led to their apprehension of the need for individualized instruction for students who struggle to write well. "It's [writing instruction] very individualized, and that's really hard in the classroom with 30 students in 50 minutes" (Elizabeth). Teachers recognized both the needs of students with disabilities for more intensive instruction and the nature of writing instruction as demanding individual guidance, and struggled to find time to respond effectively to the large numbers of students they taught:

Because every child is so different ... it's such a cliché, but those differences come out in their writing. And every child's expression is different. Every child's needs, every child's areas that he or she needs to work on, all are different. And they, it demands an individualized response. And sometimes we're able to give that, and frankly, sometimes we're not. (Lillian)

Teachers were keenly aware of the effectiveness of individualized feedback for improving writing: "It demands an individualized response." They had difficulty, however, finding the time to respond to each student's work. They spoke of coming in early and staying late, helping students during lunch, calling students at home outside school time, and spending untold hours responding to student papers:

And, younger teachers come to me, and, just say, "Oh, my God! What do you do? How do you do this?" And I say, well, you drink a lot of coffee. You stay up till 2 in the morning one night a week. You stay at work till 8 o'clock one night a week. Or you get up at 4, and you do it. Or, you spend your entire Saturday, or your entire Sunday, some days, both days, during semester exams. If I ask them to write on exams, it is not uncommon for me to sit and grade 10 hours a day over the weekend. (Lillian)

Although teachers believed individual feedback and support for students was absolutely essential to helping students make progress in their writing, they all bemoaned the enormous time demands of teaching writing well. All three, however, believed writing instruction was important enough to make personal sacrifices in order to do it well.

Teachers' concern for each student as an individual also included knowledge of the importance of making personal connections with students and a conscious sensitivity to affective characteristics of their students. Teachers believed that students learned more when they perceived that the teacher cared about the subject matter and about them, personally:

And then sometimes my students with special needs will bring me something that they've started, and they'll just want a check or a pat on the back, you know, is this OK? Am I on the right track? Sometimes they need a little bit of feedback. (Lillian)

Teachers saw writing as an effective way to show each student their concern for the individual: 
We live and we work in a system where a lot of times kids don't get treated as individuals. They're in groups, and they're treated as part of a group, and writing is one of the few ways that we can connect with them as individuals. So, I think it's vital. But it's, I think of it as a beautiful struggle, because it is. It's a beautiful thing, but it's really hard to do. (Lillian)

Teachers' knowledge of pedagogy included a deep understanding of adolescents' need to connect with others and to be seen as an individual. This is especially important to young adolescents for whom major psychological concerns include socialization and the establishment of individual identity. All of the teachers had some understanding of these needs of adolescents, although the depth of their understandings and knowledge of how to support students in those areas varied in the data. They also believed they could establish a "relationship through writing with them" that would serve both to further their instructional aims and strengthen their connection to students (Lillian).

Teachers also knew that adolescents have powerful emotions, and they were careful to consider students' affective needs when designing instructional activities. "And so, what I've tried to do for three years now is really capitalize on that, and to use that emotion and those feelings that they have right then to try to do something about it in writing" (Lillian). Lillian's understanding of her students' emotions allowed her to "capitalize" on the strong feelings caused by the first report card of the year in several ways. She used their feelings as an impetus for writing, tapping into a situation wherein students were somewhat more likely to be intrinsically motivated to express their feelings. The writing also served as an outlet for their strong emotions. In addition, she was able to provide students with an authentic opportunity for writing; connecting academics to students' lives increases motivation. Finally, the activity likely strengthened her connections to students by demonstrating that she valued and was interested enough in the events of their lives to build a unit around their shared experience.

Teachers made use of their knowledge of students' affective characteristics to choose not only specific activities, but also levels of difficulty for tasks in an effort to build students' intrinsic motivation to complete tasks:

They are so used to failing, or not succeeding, that they're so quick to shut down. So, for me, my goal is just to constantly have them wanting to move forward. And sometimes that comes from a really simple assignment... Because when you've been taught that you're going to fail at everything, then, why try? (Elizabeth)

Elizabeth was sensitive to how her students probably experienced school and how they were likely to react to repeated failure. She used a "simple assignment" to help build their confidence in their abilities and encourage them to keep trying. In this case, the simple assignment was a component part of a larger task, and Elizabeth was also providing students with multiple opportunities for success on the way to completing the larger task and breaking the task into "attainable pieces, where they can feel success." She drew on her knowledge of: content, to analyze the task and break it into logically sequenced parts; students, to understand their need to experience success in some way; and pedagogy, to ensure students got the support they needed to successfully complete the task.

The last dimension of teachers' pedagogical knowledge that emerged from the data was an understanding of the use of repetition for struggling learners. Teachers had a 
nuanced notion of repetition that was more than just repeating the same activity or task over and over:

The repetition is very important, but it needs to be interesting repetition. So if you work on setting today in one way, you need to work on setting tomorrow in another way because the same way, it's just going to be like, well, yesterday's a waste. We had to try again. And the students pick up on wasted days. And they realize that they didn't get anywhere. And that is not motivating to them, to feel like every day they do the same thing. (Elizabeth)

Elizabeth emphasized the importance of repetition for student learning, but also stressed the need for creative re-presentation or "interesting repetition." Her rationale included her concern with students affect, as well, in her determination to provide opportunities for repetition that did not make students feel as though they had wasted previous days in the class or failed to learn.

\section{Teachers' Own Beliefs and Values}

Teachers' beliefs about students with disabilities and about the content area of writing emerged as a significant component of their understandings of teaching writing to students with disabilities. The teachers expected that all of their students would be able to make progress in writing over the course of the year:

I believe really strongly that if a kid with disabilities is in my classroom, that I'm really not going to necessarily make what I'm asking that kid to do easier. Because in many cases, in most cases I find the kid can do it. And the kid takes great pride in doing it. (Lillian)

Teachers believed that all students were capable of making some progress, and that it was their job to make sure that they did:

I think that they're just, you know, one more student in the class, and that they are unique and important and have the same things to offer, you just have to find it in different ways and you have to find out what they're good at. And, start from where they are and build forward. I mean, as with every student, they may start at a different place from their neighbour, but they can still progress forward. (Elizabeth)

These teachers did not make things easier for students with disabilities, believing instead that student effort in conjunction with knowledgeable guidance would engender student progress. Their beliefs about the ability of students with disabilities to make progress in the general curriculum were supported by their knowledge of content and pedagogy. Implicit in their statements is the belief that they were able to help students make progress.

The belief that writing instruction is vitally important also emerged clearly. "I've devoted my life to that [teaching writing] ... because it's one of the major ways people communicate" (Nancy). Teachers' convictions that writing is important stemmed not from any commitment to the discrete act of writing itself but from their awareness of writing as a communicative process. "It's so important. It's important for people to learn to communicate with each other" (Elizabeth). In addition, teachers understood writing as a way for students not only to communicate, but also to release tension: "I think it's absolutely vital that young people get a chance to express themselves and to vent and to put their emotions and their experiences on paper and for those to be valued" (Lillian). 
The belief that writing instruction is vitally important inspired teachers to persevere in finding successful approaches and to devote great amounts of time to interacting with students and student work. The teachers believed that the teaching of writing requires enormous teacher dedication. They seemed to pride themselves on the amount of work they demanded from their students and the number of hours they spent reading it outside of school. They were adamant that a huge investment of teacher time and effort was necessary to produce gains in student writing:

You have to be dedicated to writing instruction, that you go home and that you read their writing and provide them feedback and constantly be tailoring tomorrow's lesson to what you saw a lack of yesterday or what you saw them sort of get and need to improve on. It's a constant reassessment of your pace and your focus. (Elizabeth)

Elizabeth reported spending hours responding to students' journal and providing students with written feedback. Her subsequent lessons were directly influenced by the work she read each evening. She was determined to find better ways to approach instruction. Nancy brought her students' journals home every weekend:

It takes me an hour and a half a week, at least, every week. It does. It takes a lot of commitment. And it, it's harder for me at the beginning of the year. Now I feel like I know my students.

All of the teachers echoed similar levels of commitment to reading student writing of various kinds. They reiterated the importance of providing regular feedback to students. The teachers' work was informed by changes in students' performance and was responsive to students' work.

\section{Context}

Teachers' understandings of writing instruction were influenced by their context. Context includes the various influences that combine to make each classroom a unique environment: classroom factors, school and administration characteristics, school district characteristics, state-level tests, and the U.S. federal government, for example. Because they were embedded in a matrix of interactive contextual influences, teachers negotiated a complex system of demands that at times conflicted with what they considered to be the students' needs. Teachers responded to several constituencies through the instructional choices they made.

The U.S. federal and state governments exerted a significant influence on these teachers' instruction. The Every Student Succeeds Act (ESSA, 2015) demands that students with disabilities be included in standardized tests administered by the states for holding schools accountable for student learning. For the Florida Comprehensive Achievement Test (FCAT) students produce 45 minutes of writing on an assigned topic that is either narrative or persuasive. "They need just fluency sometimes, because, again, on the FCAT, they've got just 45 minutes and they have to produce a volume of some sort, or they're done for," said Nancy. Nancy disagreed with that method of testing, and believed that it was contrary to accepted knowledge within the discipline about the importance of students understanding writing as a process. However, she prepared her students to perform on the state test despite her disdain for the test. The other teachers 
also acknowledged the influence of the demands of the FCAT writing test on their understandings of writing instruction: "What I teach in writing is driven definitely by the FCAT," said Lillian and, "Nothing they're going to see on the FCAT is ever going to be exciting. But they need to know that it doesn't matter, that their abilities transcend the limits of a boring topic," said Elizabeth. Teachers' understandings of writing instruction included knowledge of how to prepare students to perform the kinds of writing tasks demanded of students on the test. Although teachers' opinions about the usefulness of the testing in general varied in intensity, all acknowledged the strong influence of the test on instructional decisions.

The concerns of the principal and the school and district administrations also influenced teachers' understandings of writing instruction for struggling students. "It's that bottom $25 \%$ of kids that really impacts school grade. So, if we can, that's the goal, to try to get them learning as much as they can," said Lillian. One principal exerted a direct influence on his teachers' understandings of writing instruction by incorporating information about teaching writing into faculty meetings:

We have a principal who's very involved in pedagogy and so he's tried to make it his goal to show us ways to incorporate writing into classrooms, and the idea of how to organize thoughts, and things like that. (Nancy)

Nancy incorporated the principal's suggestions into her understandings of writing instruction, as did Lillian, who taught in the same school.

Although the pressure to prepare students to perform well on the test was strong, teachers did not limit instruction entirely to test preparation:

So, I start with ideas, and I start with a creative writing unit, just to draw that out of them, the creativity, the ideas, the, don't worry about your sentence structure right now. Let's just get good ideas on paper. (Elizabeth)

For Elizabeth, helping students generate creative ideas was an integral part of writing. She provided a lot of assists for generating ideas, such as writing notes from class discussions about ideas related to the upcoming writing project on the board, or allowing students to work in small groups to talk about ideas for writing. This particular approach was conceived to be in concert with students' needs, but did not directly prepare students to write on demand as required by state writing assessments.

\section{Discussion}

In sum, teachers' understandings of writing instruction for students with disabilities were influenced by their knowledge of content and pedagogy, their beliefs about students and writing, and the context within which they worked. They were able to choose essential aspects of instruction to focus on, and they understood the needs of students with disabilities for motivation, direct and explicit instruction, scaffolding, repetition, and consideration of their affective characteristics. They believed that students could progress in the curriculum, and that what they were teaching was vital for students to master. They negotiated a variety of contextual demands and responded to contextual influences, and the various domains of their understandings of writing 
instruction for students with disabilities informed and supported one another as they sought to enhance student progress.

The results of the study illustrated that the participating teachers believed all students can make progress and that it was the teachers' responsibility to help students do so. Researchers found similar findings related to teachers' beliefs about instruction for students with disabilities: Teachers' beliefs about teaching students with disabilities seem to be overwhelmingly supportive (Kiely et al., 2014); however, the study teachers also had a strong sense of responsibility for students' learning. Other researchers have found teachers' sense of responsibility varied over a wide range (e.g., Schumm et al., 1995).

Finally, the teachers in the study had strong beliefs regarding the importance of writing and viewed writing as a fundamental communication process. They also believed that writing instruction demands a great deal of time and a considerable amount of perseverance by teachers. Their views largely support the recent recommendations for the explicit instruction of writing strategies within a model-practise-reflect instructional cycle for secondary level writing (Graham et al., 2016). The teachers emphasized the recursive nature of their work and reiterated how they aim to build students' abilities to accomplish tasks of gradually increasing difficulty with more independence.

\section{Implications and Future Research}

Such supportive knowledge and beliefs on the part of the study teachers warrant further investigation. Pajares's (1992) review of the literature on teachers' beliefs suggested that teachers' beliefs are organized in systems, but these systems need more research. Most notably, little is known about the relationships between teachers' beliefs and practices. The teachers in the study had strong beliefs about students' abilities to learn, teachers' responsibilities, and the importance of their subject area. Little is known, however, about how teachers' beliefs are related to their practices (Jordan et al., 2010), especially for secondary grades.

The teachers were knowledgeable about writing, pedagogy, and students' needs; and they believed writing was vitally important for their students to learn. Their work, however, was hampered by the large numbers of students for whom they were responsible and by the limited amount of time during which they had access to students. Whereas the instruction they provided was overwhelmingly competent and supported by strong rationales that wove together understandings relevant to each of the domains uncovered in the data, teachers had received no formal training in how to instruct students with disabilities. Such training would enhance their ability to provide instruction to the students with disabilities who resist progress in the general education curriculum. For both new and experienced teachers, professional development in explicit instruction and strategies (Graham et al., 2016) would be beneficial. Lesson study can offer an organizing structure for facilitating conversations among general and special education teachers in inclusive classes (Benedict, Park, Brownell, Lauterbach, \& Kiely, 2013).

The teachers in the study were remarkably experienced, dedicated, and knowledgeable, and provided explicit instruction; however, students with disabilities need more than other students: more individual instruction, more explicit instruction and 
modeling, more repeated practice, and more feedback. The teachers in this study repeatedly emphasized the sheer work load involved with teaching writing; additional resources might be allocated or created for writing instruction to reduce the student and class load for teachers who bear the bulk of the responsibility for writing instruction, usually the language arts teacher. Teachers consistently judged their students to be in need of more intensive, individualized instruction; but they were constrained in their ability to provide such instruction given the way their responsibilities are currently conceived and structured. Extra time is also needed in order to process and respond to student writing with the frequency and the level of analysis teachers saw as most beneficial to students who struggle.

Why were these teachers able to do so well in such challenging contexts? The teachers were chosen for their large amount of experience and willingness to work with students with disabilities, but a closer look at other protective features the teachers identified included: professional development for the teachers, opportunities to observe other teachers, having successful experiences, and having student teachers. The studied teachers were reflective and knowledgeable; professional development that promotes reflective thinking and analysis of the connection between knowledge and practice seem productive. These teachers also evinced a high degree of care for their students. It seems activities that cultivate an ethic of care for students and learning might be important for researchers. Finally, the roles of both persistence and creativity in teaching students with disabilities bear investigating. Teachers reported efforts to solve problems of practice and continued to devise new ways to help students succeed.

\section{References}

Adams, G. L., \& Engelmann, S. (1996). Research on direct instruction: 25 years beyond DISTAR. Seattle, WA: Educational Achievement Systems.

Bender, W. N., Vail, C. O., \& Scott, K. (1995). Teachers' attitudes toward increased mainstreaming: Implementing effective instruction for students with learning disabilities. Journal of Learning Disabilities, 28(2), 87-94. doi:10.1177/002221949502800203

Benedict, A. E., Park, Y., Brownell, M. T., Lauterbach, A., \& Kiely, M. T. (2013). Using lesson study to align instruction within the Response to Intervention framework. TEACHING Exceptional Children, 45(5), 22-30. doi:10.1177/004005991304500503

Bereiter, C., \& Scardamalia, M. (1987). The psychology of written composition. Hillsdale, NJ: Lawrence Erlbaum.

Berry, R. A. (2006). Beyond strategies: Teacher beliefs and writing instruction in two primary inclusion classrooms. Journal of Learning Disabilities, 39(1), 11-24. doi:10.1177/00222194060390010301

Bruner, J. S. (1978). The role of dialogue in language acquisition. In A. Sinclair, R. J. Jarvelle, \& W. J. M. Levelt (Eds.), The child's conception of language (pp. 241-256). New York, NY: Springer-Verlag.

Buehl, M. M., \& Beck, J. S. (2014). The relationship between teachers' beliefs and teachers' practices. In H. R. Fives \& M. G. Gill (Eds.), International handbook of research on teacher beliefs (pp. 475-491). New York, NY: Routledge. doi:10.4324/9780203108437 
Coladarci, T., \& Breton, W. A. (1997). Teacher efficacy, supervision, and the special education resource-room teacher. The Journal of Educational Research, 90(4), 230-239. doi:10.1080/00220671.1997.10544577

Cunningham, A. E., Zibulsky, J., Stanovich, K. E., \& Stanovich, P. J. (2009). How teachers would spend their time teaching language arts. Journal of Learning Disabilities, 42(5), 487-510. doi: $10.1177 / 0022219409339063$

Every Child Succeeds Act (ESSA) of 2015, Public Law No. 114-95, S.1177, 114th Cong. (2015). Retrieved from https://www.congress.gov/114/plaws/pub1195/PLAW-114pub195.pdf

Fang, Z. (1996). A review of research on teacher beliefs and practices. Educational research, 38(1), 47-65. doi:10.1080/0013188960380104

Fenstermacher, G. D. (1994). Chapter 1: The knower and the known: The nature of knowledge in research on teaching. Review of Research in Education, 20(1), 3-56. doi:10.3102/0091732x020001003

Fernandez, C. (2014). Knowledge base for teaching and pedagogical content knowledge (PCK): Some useful models and implications for teachers' training. Problems of Education in the 21st Century, 60, 79-100.

Florida Department of Education. (2008). School district data. Retrieved from www.fldoe.org

Graham, S., Bruch, J., Fitzgerald, J., Friedrich, L., Furgeson, J., Greene, K., ... Smither Wulsin, C. (2016). Teaching secondary students to write effectively (NCEE 2017-4002). Washington, DC: National Center for Education Evaluation and Regional Assistance (NCEE), Institute of Education Sciences, U.S. Department of Education. Retrieved from http://whatworks.ed.gov

Graham, S., Harris, K., MacArthur, C. A., \& Fink, B. (2002). Primary grade teachers' theoretical orientations concerning writing instruction: Construct validation and a nationwide survey. Contemporary Educational Psychology, 27, 147-166. doi:10.1006/ceps.2001.1085

Graham, S., Harris, K. R., \& Mason, L. (2005). Improving the writing performance, knowledge, and self-efficacy of struggling young writers: The effects of Self-Regulated Strategy Development. Contemporary Educational Psychology, 30, 207-241.

Grossman, P., \& Stodolsky, S. (1994). Considerations of content and the circumstances of secondary school teaching. In L. Darling-Hammond (Ed.), Review of Research in Education, 20, 179222. Washington, DC: American Educational Research Association.

Grossman, P. L., \& Stodolsky, S. S. (1995). Content as context: The role of school subjects in secondary school teaching. Educational Researcher, 24(8), 5-11, 23.

Grossman, P., Wilson, S., \& Shulman, L. (1989). Teachers of substance: Subject matter knowledge for teaching. In M. C. Reynolds (Ed.), Knowledge base for the beginning teacher (pp. 23-34). Oxford, UK: Pergamon Press. doi:10.1080/1047621910040129

Hiebert, J., Gallimore, R., \& Stiegler, J. (2002). A knowledge base for the teaching profession: What would it look like, and how can we get one? Educational Researcher, 31(5), 3-15. doi:10.3102/0013189x031005003

Jordan, A., Glenn, C., \& McGhie-Richmond, D. (2010). The supporting effective teaching (SET) project: The relationship of inclusive teaching practices to teachers' beliefs about disability and ability, and about their roles as teachers. Teaching and Teacher Education, 26(2), 259266. doi:10.1016/j.tate.2009.03.005

Kang, N. H., \& Wallace, C. S. (2004). Secondary science teachers' use of laboratory activities: Linking epistemological beliefs, goals, and practices. Science Education, 89(1), 140-165. doi:10.1002/sce.20013 
Kiely, M. T. (2017). Enhancing instruction for students with academic needs: Strategies for writing skills. In L. Gibson \& F. E. Obiakor (Eds.), Computer based technology for special and multicultural education: Enhancing 21st century learning (pp. 93-114). New York, NY: Plural Publishing.

Kiely, M. T., Brownell, M. T., Benedict, A., \& Lauterbach, A. L. (2014). Teachers' beliefs about students with special needs and inclusion. In H. R. Fives \& M. G. Gill (Eds.), International handbook of research on teacher beliefs (pp. 475-491). New York, NY: Routledge. doi:10.4324/9780203108437

Moni, K. B., Jobling, A., van Kraayenoord, C. E., Elkins, J., Miller, R., \& Koppenhaver, D. (2007). Teachers' knowledge, attitudes and the implementation of practices around the teaching of writing in inclusive middle years' classrooms: No quick fix. Educational and Child Psychology, 24(3), 18-36.

Munby, M., Russell, T., \& Martin, A. K. (2001). Teachers' knowledge and how it develops. In V. Richardson (Ed.), Handbook of research on teaching (4th ed., pp. 877-904). Washington, DC: American Educational Research Association.

Pajares, F. (1992). Teachers' beliefs and educational research: Cleaning up a messy construct. Review of Educational Research, 62, 307-332.

Schumm, J. S., Vaughn, S., Haager, D., McDowell, J., Rothlein, L., \& Saumell, L. (1995). General education teacher planning: What can students with learning disabilities expect? Exceptional Children, 61(4), 335-352. doi:10.1177/001440299506100403

Scruggs, T. E., \& Mastropieri, M. A. (1996). Teacher perceptions of mainstreaming/inclusion, 19581995: A research synthesis. Exceptional Children, 63(1), 59-74. doi:10.1177/001440299606300106

Shulman, L. S. (1986). Paradigms and research programs in the study of teaching: A contemporary perspective. In M. C. Wittrock (Ed.), Handbook of research on teaching (3rd ed., pp. 3-36). New York, NY: MacMillan.

Snyder, T. D., de Brey, C., \& Dillow, S. A. (2018). Digest of education statistics 2016 (NCES 2017094). Washington, DC: National Center for Education Statistics, Institute of Education Sciences, U.S. Department of Education.

Spradley, J. P. (1979). The ethnographic interview. Orlando, FL: Harcourt, Brace, \& Jovanovich.

Talbert, J. E., McLaughlin, M. W., \& Rowan, B. (1993). Understanding context effects on secondary school teaching. Teachers College Record, 95(1), 45-68.

Troia, G. A., \& Graham, S. (2002). The effectiveness of a highly explicit, teacher-directed strategy instruction routine changing the writing performance of students with learning disabilities. Journal of Learning Disabilities, 35(4), 290-305. doi:10.1177/00222194020350040101

Wehmeyer, M., Shogren, K., Toste, J., \& Mahal, S. (2016). Self-determined learning to motivate struggling learners in reading and writing. Intervention in School and Clinic, 52(5), 1-9. doi: $10.1177 / 1053451216676800$

\section{Author's Note}

Partial support for this project was provided by a PSC-CUNY Award, jointly funded by the Professional Staff Congress and The City University of New York.

Correspondence concerning this article should be addressed to Dr. Mary Theresa Kiely, Graduate Programs in Special Education, Department of Educational and Community Programs, Queens College, City University of New York, 65-30 Kissena Boulevard, Queens, NY, 11367, U.S.A. Email: mary.theresa.kiely@qc.cuny.edu 